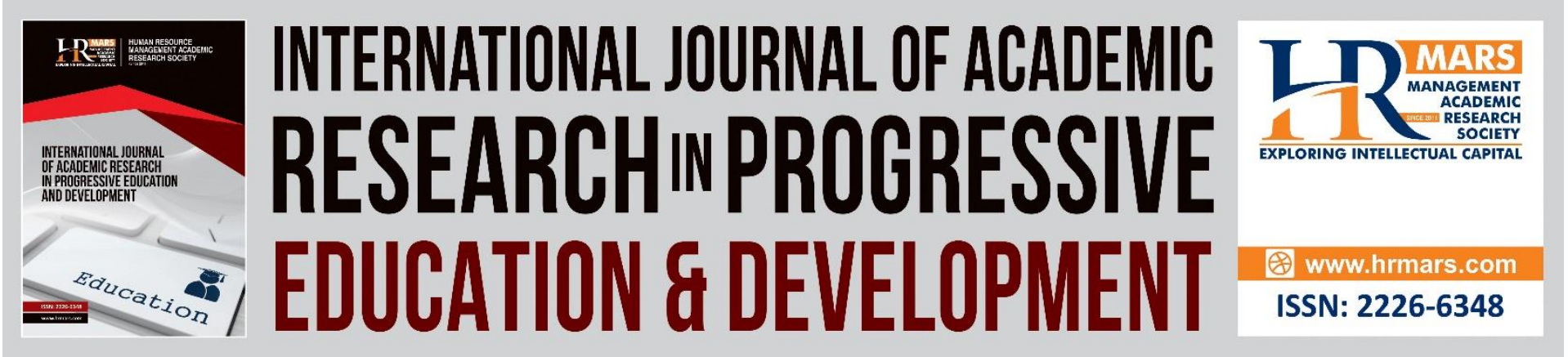

\title{
The History of the Qur'anic Enigma and the Impact of Interpretation in Directing it
}

Mohamed Fathy Mohamed Abdelgelil, Mahmoud Fathy Mohamed Abdelgalil Osman, Reda Owis Hassan Serour, Mukhamad Hadi Musolin Subagio, Ammar Kamal Ibrahim Othman, Ahmad Fauzi Hassan

To Link this Article: http://dx.doi.org/10.6007/IJARPED/v10-i3/10973

DOI:10.6007/IJARPED/v10-i3/10973

Received: 14 July 2021, Revised: 18 August 2021, Accepted: 02 September 2021

Published Online: 21 September 2021

In-Text Citation: (Abdelgelil et al., 2021)

To Cite this Article: Abdelgelil, M. F. M., Osman, M. F. M. A., Serour, R. O. H., Subagio, M. H. M., Othman, A. K. I., \& Hassan, A. F. (2021). The History of the Qur'anic Enigma and the Impact of Interpretation in Directing it. International Journal of Academic Research in Progressive Education and Development, 10(3), 412-418.

Copyright: (C) 2021 The Author(s)

Published by Human Resource Management Academic Research Society (www.hrmars.com)

This article is published under the Creative Commons Attribution (CC BY 4.0) license. Anyone may reproduce, distribute, translate and create derivative works of this article (for both commercial and non-commercial purposes), subject to full attribution to the original publication and authors. The full terms of this license may be seen

at: http://creativecommons.org/licences/by/4.0/legalcode

\section{Vol. 10(3) 2021, Pg. 412 - 418}

Full Terms \& Conditions of access and use can be found at http://hrmars.com/index.php/pages/detail/publication-ethics 


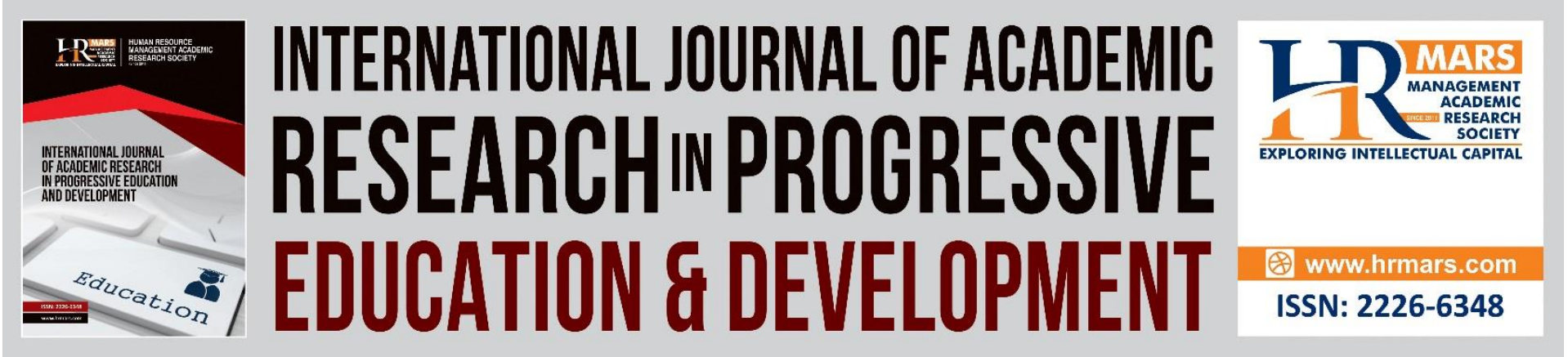

\title{
The History of the Qur'anic Enigma and the Impact of Interpretation in Directing it
}

\author{
${ }^{1}$ Mohamed Fathy Mohamed Abdelgelil, ${ }^{3}$ Mahmoud Fathy \\ Mohamed Abdelgalil Osman, ${ }^{2}$ Reda Owis Hassan Serour, \\ ${ }^{2}$ Mukhamad Hadi Musolin Subagio, ${ }^{1}$ Ammar Kamal Ibrahim \\ Othman, ${ }^{1}$ Ahmad Fauzi Hassan \\ ${ }^{1}$ Faculty of Islamic Contemporary Studies (FKI), Sultan Zainal Abidin University (UniSZA), \\ 21300, Terengganu, MALAYSIA, ${ }^{2}$ Sultan Abdul Halim Mu'adzam Shah International Islamic \\ University, (UniSHAMS), Malaysia, ${ }^{3}$ Sharjah Islamic Affairs, The United Arab Emirates (UAE) \\ Email: mfathy@unisza.edu.my
}

\begin{abstract}
The Qur'an was revealed to guide human beings and to bring guidance and happiness to them, but the confusion in understanding some of its verses comes either from someone who slanders the religion and wages war against Allah Almighty and His Messenger, sparing no effort in antagonizing the Qur'an and its followers, in order to overthrow it and degrade its value; Such people started with the beginning of the revelation of the Qur'an, and they said many sayings about it, seeking to discredit it, including their saying: It is magic, fortune-telling, myths of the ancients, or other things that were a path followed by those who came after them from the hypocrites and heretics atheists, and they developed other ways to slander the Qur'an, its language, and its source. Accordingly, the research shows interpretation as one of the paths of solving the Qur'anic enigma, as well as the history of the Qur'anic enigma. The research is based on the analytical approach in order to track the positions in which the people of interpretation supported the Qur'anic readings. It has been concluded from this research that the interpretation has a major role in solving the Qur'anic enigma, and that the one who says some problems about the Holy Qur'an are not only from the infidels, but may be from Muslims, but from the people of knowledge, in terms of his desire to reach knowledge, and not doubt the Holy Qur'an. Also, the Qur'anic enigma appeared since the time of the Noble Prophet when some of the companions were confused about some Qur'anic terms, and the first book that reached us that singled out the Qur'anic enigma is the book of Qutrub, and it relied on syntax, then it was followed by the book of al-Fara' and it was more inclusive than it.
\end{abstract}

Keywords: Interpretation, Directing, Quran, Hadith, Quranic Enigma

\section{Introduction}

The researcher in Qur'anic sciences finds the subject of directing the Qur'anic enigma a great interest among the interpreters, may Allah Almighty bless them, whether it is in directing 
Qur'anic readings in general, or guiding Qur'anic vocabulary that is enigmatic in particular, and this science is like other sciences that started limited and then expanded and had their own books.

\section{Preface}

To direct the Qur'anic enigma there are many paths, such as grammar, syntax, rhetoric, morphology, Arabic languages, and other many paths taken by scholars in general and the people of interpretation in particular. There is also a path that helps directing the Qur'anic enigma, which is interpretation, and this research shows this part.

\section{The Qur'anic Enigma by the People of Islam}

The Qur'anic enigma may be related to the Qur'an and its verses by the people of Islam, and this is divided into two parts:

The first: That the enigma arises from a person with a suspicion that blinds him from accepting the truth. Someone who follows his whims, misguides the servants of Allah, and commits what helps heretics and atheists to slander religion, as is the case of the Jahmiyyah and those who follow their way. For such people the argument is established against them, and the truth is made clear to them.

And the second: What is the confusion of the people of knowledge with some verses of the Qur'an, or the concealment of some of what is happening because of an illusory contradiction, or a similarity that needs to be collected and clarified. This results in the contemplation of the texts, and the search for clarification of this problem. In such a case the superiority of knowledge and its people appears over those without them. The glory and honor of the Book of Allah, the Exalted, is showed by the need to search for its secrets and wonders.

The one who contemplates on the Book of Allah Almighty will find in it what enlightens his insight to the truth, removes the illusion of differences and contradictions between its verses, and removes many of the enigmas in it. In this regard, Ibn al-Qayyim, may Allah have mercy on him, says (d. 751): If the one with insight from Allah contemplates the method of the Qur'an and the Sunnah, he will find that it is inclusive to eliminate what is imagined by speech contrary to what it shows. This is a very nice point to understanding the Qur'an, we will refer to some of it, and from that is the Almighty's saying: (And Allah spoke to Moses with [direct] speech.) (Quran, An nissaa: 164),Glory be to Him, raised the illusion of metaphor in His speaking to Moses with a definite source, which the true Arab does not doubt that what is meant by it is to prove that truth, as the Arabs say: He is dead. He descended a quick descent. (Absolute Object) (Ibn Al-Qayyim, 1988, 1/389).

Under the enigma of the Qur'an, is everything related to the confusion over the source of the Qur'an, its words, meanings, context, rulings, unification, readings, written form, syntax, and rhetorical methods, and the illusion of difference and contradiction between its verses, or between its verses and the correct and explicit prophetic hadiths.

\section{History of the Qur'anic Enigma}

Problems in understanding the meaning of the verses have started since the time of the Prophet, may Allah bless him and grant him peace, and some of the companions, may Allah be pleased with them, were confused about understanding the meaning of the "white thread" and the "black thread" in the Almighty's saying: (وَAnd eat and drink until the white thread of dawn becomes distinct to you from the black thread [of night].) (Quran, Al-Baqarah: 
187)Which which required the Prophet, may Allah's prayers and peace be upon him, to clarify what was meant by the verse, as well as the confusion of the Companions, may Allah be pleased with them, about the meaning of injustice in the Almighty's saying: (They who believe and do not mix their belief with injustice - those will have security, and they are [rightly] guided.) (The Qur'an, Al-An'am: 82) which required that the Prophet, may Allah bless him and grant him peace, to explain to them the intended meaning in the verse, that what is meant by it is polytheism, as stated in the Almighty's saying: (Indeed, association [with him] is great injustice.) (Quran, Luqman: 13).

The first book that reached us in which its author was exposed to the enigma in the title and content is the book "The Meanings of the Qur'an and the Interpretation of the enigma of Its Syntax" by Al-Mustanir (d. 206), but his speech in the enigma is specific to what is related to syntax, as is clear in the title of his book.

And Qutrub makes for the enigma of syntax in his book a separate chapter on the surah's that he interprets by saying: "Interpretation of the enigma of syntax in surah so-and-so" or something like this, and he is limited to explaining what he sees as problematic in the syntax without asking questions about it, and the title of his book is indicative of that.

He is followed by Al-Fara' (d. 207) in his book "The Interpretation of the Enigmatic Syntax of the Qur'an and its Meanings." Al-Fara' came in the second rank after Qutrub, although they were contemporary; because al-Farra wrote his book after al-Baghdadi (d. 463) indicated that the first to classify this from among the people of the language was Abu Ubaidah Muammar ibn al-Muthanna, then Qutrub ibn al-Mutanir, then al-Akhfash, and classified among the Kufis, al-Kisa 'i, then al-Fara'" (Al-Khatib) Al-Baghdadi, 2002, 14/392.

And if al-Farra's intention in authoring this book was to explain what he sees as enigmatic of meanings and syntax, and considers that everything that he explained in it is what he thought as enigmatic, then according to this it is considered the first book that reached us on the enigma of the Qur'an as a title and content. It follows the order of the surahs of the Qur'an. Al-Farra deals with problems during his interpretation of the verses, and his confusion is often made by asking questions about what needs to be answered, such as saying: "If someone said: So-and-so", Or, "it is said: So-and-so", and the like, then comes the problem, and he answers it.

Problems vary between meanings, styles, and syntax; rather, most of the examples (the enigma with the meanings of the Qur'an) that were previously mentioned in this research are from Al-Farra's, as the enigmas presented by him amount to more than eighty enigmas.

Al-Farra's method of eliminating enigmas and solving them was in a variety of ways, including: Solving the enigma with the Qur'an, (Al-Fara', 1990, 2/82, and 3/302), the readings (Al-Fara', 1990, 3/156), and the reasons for revelation (Al-Fara 1990, 1/20, 1/182, 1/336). The sayings of the Followers (Al-Fara', 1990, 1/111, 2/276), and the Isra'iliyat, (Al-Fara', 1990, 1/289, $2 / 51$ ). Arabic analogy and syntax, (Al-Fara', 1990, 1/150, 2/108), and some rhetorical styles (Al-Fara', 1990, 1/371, 1/476). The title of his book indicates the including of meaning, syntax, and others in which the enigmas related to them need declaration and clarification.

Al-Akhfash was among those who mentioned some of the enigmas in his book "The Meanings of the Qur'an", but they are very few, and their number does not reach ten. The method of his confusion was by asking questions while explaining the verses, such as saying: "If it is said: So-and-so", or "If someone says: So-and-so", and so on (Al-Akhfash, 1990, 1/21, 2/452.) Imam Ahmad responded to slanders regarding what they imagined about the differences and contradictions in the verses of the Qur'an, in the book attributed to him, "The Response to 
the Heretics and the Jahmiyyah", where the first part of it was devoted to explaining what the heretics misled (Al-Fayumi, 2002, 1/256) from the similarities of the Qur'an (Ibn Hanbal, 2010, 58), in which he mentioned twenty-two issues, and he eliminated what they imagined was difference and contradiction by clarifying the correct meaning that the verse should imply, and combining the meanings of the verses in which the contradiction is suspected of that as well.

The second section according to Imam Ahmad in the debate of the Jahmiyyah and the response to them is considered under what is problematic in the Qur'an from the doctrinal point of view.

Ibn Qutayba's book "The Interpretation of the Enigma of the Qur'an" is considered the first book to reach us regarding the problem of the Qur'an in its title and content, in the objective order of the Qur'an's enigma. He is the first to include the refutation of the claims of the slanderers under the enigma of the Qur'an, however, the majority of the slanderers claims to him are in the illusion of difference and contradiction in the verses of the Qur'an.

Ibn Qutayba divided the enigma in his book into four sections:

The first: Refuting the claims of the slanderers in matters that are not related to the meanings, and under which lies the slander in the Qur'an through the readings, and through the written form of the Qur'an

The second: What is believed to be a difference and contradiction, and this is either in the context of the verse, or between the meaning of one verse and another.

The third: The enigma of similarity, due to confusion and ambiguity in the meaning, and includes what illusions the corruption of the composition of separate letters, and others.

Fourth: The linguistic enigma, which in his view is subordinate to the similarity enigma, and he means by it what is related to the deviation of speech from the apparent requirement, and from the origin of what was made for it; It includes some cases of syntax, sections of metaphor, allegory, inverted - including anastrophe -, omission and abbreviation, repetition, metonymy and intersection, opposition to the apparent meaning of the word, and other Arabic styles that he mentioned in his book, and he spoke about them in the chapter on the effect of interpretation in rhetoric.

Most of the Jahmiyyah and Mu'tazila's methods to slander the Qur'an, is by distorting its meanings from the side of language and metaphor.

Based on this, the enigmas in general regarding the Book of Allah Almighty are divided into two parts:

First Section: The refutation of the claims of the slanderers by objecting and questioning the Qur'an in something that is outside the interpretation of its verses, and is not related to the illusion of difference and contradiction between its meanings.

Second Section: What is related to the confusion that arises in the verses of the Qur'an in terms of meanings, syntax, methods, readings, etc., or what seems to be a conflict or difference between the verses in their concept, and the relationship between their meanings. This section is the most general of those who deal with the enigma of the Qur'an.

Ibn Qutayba dealt with these two sections, and clarified many of their issues in his book "The Interpretation of the Enigma of the Qur'an." Perhaps the enigma of the Qur'an is more general for him than the problem of the meanings of the Qur'an, as it includes refuting the claims of the slanderers with what is outside the meanings of the verses, and includes the confusion between the verses of the Qur'an and their meanings. 
It is obvious that Ibn Qutayba benefited in his book "The Interpretation of the Enigma of the Qur'an" from a number of those who wrote in the interpretation before him, and I may not be exaggerating if I say: That Ibn Qutayba compiled a summary of what is a directing to the enigma of the Qur'an from Abu Ubaidah Muammar bin Al-Muthanna, and Al-Far', and included it in his book, adding to that: good arrangement, rectification, eloquence, and clarification of the meaning without lengthening that is useless, or shortening that does not fulfill the purpose. Moreover, adding what he needs, selecting the correct and most correct, and refuting what he deems impermissible in the words of Allah Almighty, or in violation of the purposes of the Qur'an, or the language and speech of the Arabs.

I am not sure of his benefit in the illusion of difference and contradiction from the book attributed to Imam Ahmad, "The Refutation of the Heretics and the Jahmiyyah,", except that they agreed on some verses that heretics and atheists imagine contradicting, and perhaps that is due to the agreement of ideas, for such suspicions were widespread in their time as known.

Qutrub, al-Akhfash, al-Fara', and Ibn Qutayba share in citing the words of the Arabs and their poetry on most of what they need in terms of meanings, syntax, styles, and directing what is enigmatic in the verses as well.

Many of the interpreters' enigmas in the verses of the Qur'an are relative, due to the discrepancy between understandings, for some of them may confuse what is clear to others. Among the confusion between some interpreters is what is in the matter of asking questions to attract attention, and training the mind to think., as what marks the mind from this section is more than others, and confusion may also be from the section of what is necessary in speech, or commenting on a previous speech until the interpreters make statement of what he has regarding it.

The interpreters in the first three centuries had several methods in directing the Qur'anic enigma, and eliminating what might be an illusion of contradiction and difference between the verses of the Qur'an, including: Directing the enigma with interpretation, Directing the enigma with the readings, and with the Qur'an, whether the directing is in terms of the context, or the verses in general. In addition to directing the problem with the Sunnah, the sayings of the Companions, and the Followers, the reasons for revelation and its conditions, the syntax, and the Arab and Isra'iliyat as well for some of them; All of these sciences have the effect of directing the enigmas, and eliminating what might be illusion of a conflict and difference between the verses and meanings of the Qur'an.

\section{Conclusion}

Several results were drawn from this research, including:

1. Interpretation has a major role in directing the Qur'anic enigma.

2. The one who says some enigmas about the Noble Qur'an is not only from the infidels, but may be from the Muslims, but from the people of knowledge, in terms of their desire to reach knowledge, and he is not skeptic in the Noble Qur'an.

3. The Qur'anic enigma has appeared since the time of the Noble Prophet, when some of the Companions used some Qur'anic words.

4. The first book that reached us that singled out the Qur'anic enigma was the book of Qutrub, in which he relied on the syntax, then it was followed by the book of al-Fara', which was more inclusive than it. 


\section{References}

Al-Quran Al-Karim.

Abdelgelil, M. F. M. (2020). Grammarians' Critique of Qur'anic Qira'at. International Journal of Academic Research in Business and Social Sciences, 10(11), 1225-1231.

Abdelgelil, M. F. M. (2020). Solving the Quranic Issues with Quranic Qira'at, International Journal of Academic Research in Business and Social Sciences, 10(12), 36-42.

Abdelgelil, M. F. M., Al-Janayni, M. U., Baru, R., Hamzah, M. S., Razali, M. A. T. M., \& Ismail, F. Z. (2018). Tawjih Al-Qira'at Based on Inscription, Language, and Unusual Modes of Recitation According to Ibn Zanjalah. International Journal of Academic Research in Business and Social Sciences, 8(10), 362-370.

Abdelgelil, M. F. M., Daud, N. B., Omar, N. B., Ismail, F. Z. B., \& Wahab, A. H. B. A. (2018). Taujeeh Al-Qira'at Using Qur'an, Hadith and Poetry according to Ibn Zanjalah. International Journal of Academic Research in Business and Social Sciences, 8(10), 371-379.

Abdelgelil, M. F. M., Hasan, A. F., Yusoh, F., El khayat, M. H. M., Razali, M. A., Ismail, F. Z., \& Ab Rashid, R. (2021). Correlation Between Irregular Qiraat And Arabic Linguistics In The Quranic Tafseer Book By Al-Razi. International Journal of Academic Research in Business and Social Sciences, 11(7), 1632-1639.

Abdelgelil, M. F. M., Hasan, A. F., Yusoh, F., Ismail, F. Z., Ab Rashid, R., Ab Aziz, N. S., Hassan, A (2021). The Impact of Irregular Qiraat on Arabic Semantics and Dialects. International Journal of Academic Research in Business and Social Sciences, 11(7), 1672-1676.

Abdelgelil, M. F. M., Hasan. A. F., Yusoh, F., El khayat, M. H. M., Razali, M. A., Hassan, A., Ab Aziz, N. S. (2021). Arabic Syntactic Rules with Reference to Quranic Qurra. International Journal of Academic Research in Business and Social Sciences, 11(7), 1707-1711.

Abdelgelil, M. F. M., Musolin, M. H., Serour, R. O. H., Abdullah, M. S., \& Noor, M. N. M. (2018). Law and Moral Values in the Holy Quran. International Journal of Academic Research in Business and Social Sciences, 8(11), 445-451.

Alfaiumi, 'A. Bin M. (2002). Almisbah Almunir Fi Gharib Alsharh Alkabir. Beirut: Almaktabah Al'eilmiyah.

Alfarra', Y. B. Z. (1990), Ma'ani Alquran. Tahqiq: 'Ahmad Yusuf Alnajati, Muhammad Ali Alnajjar, Aabdulfattah 'Isma'eil Alshalabi, Alqahirah: Dar Almisriyah Lilta'alif Waltarjamah.

Albaghdadi, A., Ali, A. B. (2002). Tarikh Baghdad. Tahqiq: Dr. Bashar 'Awwad Ma'ruf. Beirut: Dar Algharb Al'islami.

Ibn Alqaiym, 'Abi Bakr, M. B. (1988). Alsawa'eiq Almursalah Fi Alrad 'Ala Aljahamiah Walmu'atilah, Tahqiq: 'Ali Bin Muhammad Aldukhil Allah. Alriyadz: Dar Al'asimah.

Ibn Hanbal, Muhammad, A. B. (2010). Alrad 'Ala Aljahamiah Walzanadiqah. Tahqiq: Sabri Salamah Shahin. Alriyadz: Dar Althabat. 